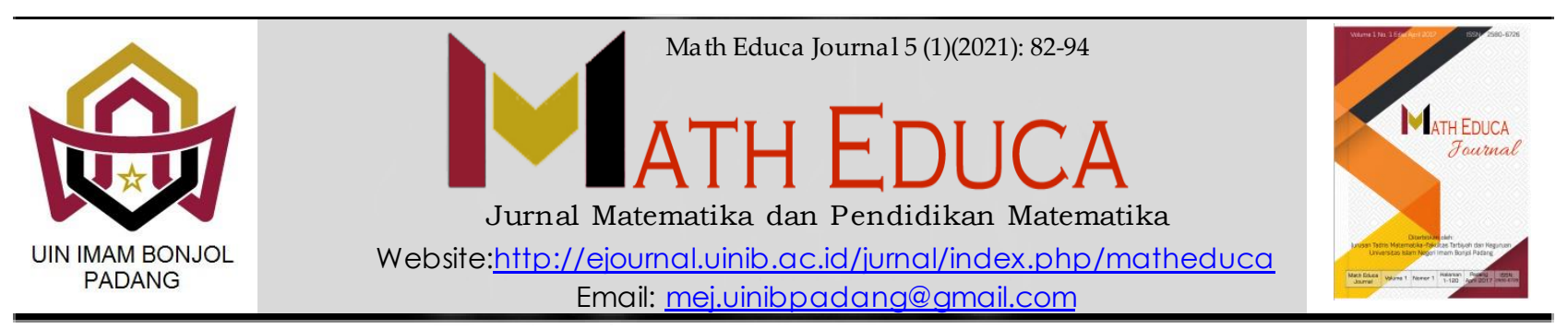

\title{
PENGARUH PENDEKATAN OPEN-ENDED TERHADAP KEMAMPUAN BERPIKIR KREATIF MATEMATIS BERDASARKAN RESILIENSI MATEMATIS SISWA MTS MUHAMMADIYAH 02 PEKANBARU
}

\author{
'Ramadani*, 2Ramon Muhandaz \\ 1,2 Pendidikan Matematika, Fakultas Tarbiyah dan Keguruan, Universitas Islam Negeri Sultan Syarif Kasim \\ Riau, Indonesia \\ Email: 'ㄹanigaung@gmail.com, ${ }^{2}$ ramon.muhan@uin-suska.ac.id
}

Received: February 2021; Accepted: March 2021; Published: April 2021

\begin{abstract}
The ability to think creatively is needed by students in mathematics learning activities, because creativity raises ideas in solving mathematical problems, so that the expected learning objectives are achieved. In addition, the mathematical resilience factor is needed to make students more persistent, never give up, enjoy being challenged, so that students' perspective on mathematics is not something to be afraid of anymore. This study aims to determine the effect of an open-ended approach on the mathematical creative thinking ability based on the mathematical resilience of Madrasah Tsanawiyah (MTs). This type of research is an experimental design that uses a factorial design. The selected population has been subjected to a one-way ANOVA test with the results having an average similarity, so that the sample was taken using the Cluster Random technique with randomly selected samples, namely class VIII-1 which was selected as the experimental class and class VIII- 2 was selected as the control class. The results showed: 1) there were differences in mathematical creative thinking skills between students learning with open-ended learning and students learning using conventional learning; 2) there are differences in mathematical creative thinking abilities between students who have high, medium and low mathematical resilience; 3) while for interaction there is no interaction between the open-ended learning approach and students' mathematical resilience to mathematical creative thinking abilities. So the results of this study can be used to improve mathematics learning in class.
\end{abstract}

Keywords : Open-ended approach, mathematical creative thinking ability, mathematical resilience

\begin{abstract}
Abstrak
Kemampuan dalam berpikir kreatif sangat dibutuhkanan oleh siswa dalam kegiatan pembelajaran matematika, karena kreativitas memunculkan ide-ide dalam penyelesaian masalah matematika, sehingga tercapailah tujuan pembelajaran yang diharapkan. Selain itu, faktor resiliensi matematis diperlukan guna membuat siswa lebig gigih, pantang menyerah, senang mendapatkan tantangan sehingga membuat sudut pandang siswa terhadap matematika bukan hal yang harus ditakuti lagi. Penelitian ini bertujuan mengetahui pengaruh pendekatan open-ended terhadap kemampuan berpikir kreatif matematis berdasarkan resiliensi matematis Madrasah Tsanawiyah(MTs). Jenis penelitian adalah eksperimen dengan desain yang digunakan desain Faktorial. Populasi yang dipilih sudah dilakukan tes anova satu arah dengan hasil memiliki kesamaan rata-rata, sehingga sampel diambil dengan teknik Cluster Random dengan sampel terpilih secara acak yaitu kelas VIII- 1 yang terpilih sebagai kelas eksperimen dan kelas VIII-2 terpilih sebagai kelas kontrol. Hasil penelitian menunjukkan:1) terdapat perbedaan kemampuan berpikir kreatif matematis antara siswa yang
\end{abstract}

\footnotetext{
${ }^{*}$ Corresponding author.

Peer review under responsibility UIN Imam Bonjol Padang.

(c) 2021 UIN Imam Bonjol Padang. All rights reserved.

p-ISSN: $2580-6726$

e-ISSN: $2598-2133$
} 
belajar dengan open-ended dengan siswa yang belajar dengan pembelajaran konvensional; 2) terdapat perbedaan kemampuan berpikir kreatif matematis antara siswa yang memiliki resiliensi matematis tinggi, sedang dan rendah; 3) sedangkan untuk interaksi tidak terdapat interaksi antara pendekatan pembelajaran open-ended dan resiliensi matematis siswa terhadap kemampuan berpikir kreatif matematis. Maka hasil penelitian ini dapat dimanfaatkan untuk peningkatan pembelajaran matematika dikelas.

Kata Kunci: Pendekatan open-ended, kemampuan berpikir kreatif matematis, resiliensi matematis

\section{Pendahuluan}

Generasi pada abad 21 harus mempunyai kemampuan yang menyesuaikan dengan perkembangan teknologi dan informasi, untuk itu perlu dibenahi dengan sikap kreatif, mampu berpikir kritis, luwes serta dapat mengambil keputusan dengan tepat, dan terampil memecahkan masalah(Sani,2019:6). Berpikir kreatif adalah suatu kompetensi/kemampuan yang mesti ada pada siswa dalam proses pembelajaran matematika untuk menjadikan siswa mempunyai banyak pemikiran/ide, rasa penasaran/ingin tahu yang tinggi, kepercayaan diri, optimis, berorientasi pada masa akan datang, hal ini diharapkan agar tujuan pembelajaran matematika dapat terwujud terkhusus pada domain berpikir kreatif matematis(Hendriana, Rohaeti dan Sumarmo., 2017:112)

Adapun indikator/kriteria berpikir kreatif Torrance (dalam Lestari \& Yudhanegara, 2017) yaitu 1) Kelancaran(fluency), artinya punya banyak ide/gagasan untuk berbagai kategori 2)Keluwesan (flexibility) artinya punya banyak ide/gagasan yang beragam. 3) Keaslian (originality), artinya punya ide/gagasan baru untuk menyelesaikan persoalan. 4) Elaborasi (elaboration), yaitu mampu mengembangkan ide/gagasan untuk menyelesaikan masalah secara rinci.Namun fakta yang ditemukan dapat dilihat dari hasil UN, dimana sebagian soal UN merupakan soal berpikir tingkat tinggi, untuk hasil UN matematika Kota Pekanbaru 2019 yaitu 46,56 untuk SMP dan 42,24 untuk MTs. Berdasarkan berbagai artikel penelitian yang telah dipublish juga mengindikasi kemampuan berpikir kreatif matematis siswa di tingkat sekolah menengah masih terbilang rendah. yaitu penelitian yang dilakukan oleh Sri Anandari Safaria dan Muhammad Syarwa Sangila yang menyimpulkan pada penelitiannya bahwa pada aspek kelancaran (fluency) 2.846 . keluwesan(flexibility)1.514, aspek keterincian (elaboration) 1.729 dan aspek keaslian (originality) hanya sebesar 1.041. selanjutnya hasil penelitian yang oleh Harry, dkk (2018) yang menyimpulkan juga bahwa kemampuan berpikir kreatif siswa masih dalam kategori rendah berdasarkan uji soal tes berpikir kreatif. Dari permasalahan yang dipaparkan, ternyata hal yang sama juga dialami di tempat peneliti melakukan penelitian berdasarkan hasil prariset. Berdasarkan hasil observasi dengan cara menguji kemampuan berpikir kreatif menunjukan hasil jawaban dari siswa masih belum bisa mengembangkan kreatifitas mereka 
dalam menjawab dan memecahkan masalah matematika selain dari yang diajarkan oleh guru disekolah. Berdasarkan fakta-fakta tersebut, maka peneliti menyimpulkan bahwa siswa belum mempunyai kemampuan berpikir kreatif matematis yang baik alias kemampuanya masih tergolong rendah.

Banyak faktor yang dapat mempengaruhi tingkat keberhasilan pada hasil belajar terkhusus pada domain berpikir kreatif. Faktorfaktor yang mempengaruhi keberhasilan belajar antara lain ada faktor internal, faktor eksternal, dan faktor pendekatan belajar. Faktor internal, meliputi faktor-faktor yang ada dari dalam diri siswa berupa rohani dan jasmani siswa, faktor eksternal meliputi faktor dari luar seperti lingkungan yang ada disekitar siswa baik lingkup sosial maupun lingkup non sosial, kemudian faktor pendekatan belajar, meliputi faktor yang mempengaruhi keberhasilan belajar siswa, antara lain strategi,pendekatan, metode yang digunakan guru dalam pembelajaran(syah, 2010).

Selain faktor tersebut, terdapat pula faktor pendekatan belajar yang membuat pembelajaran bisa lebih bermakna bagi siswa dan proses pemahaman juga cepat didapat oleh siswa, oleh sebab itu guru harus membuat suatu inovasi untuk meningkatakan hasil belajar dan mencapai tujuan pembelajaran pada aspek berpikir kreatif, ada banyak pendekatan yang dapat membuat siswa aktif diantaranya yang melatih siswa berpikir kreatif pendekatan open - ended. Pembelajaran dengan pendekatan open - ended dapat membangkitkan kegiatan interaktif antara siswa dan masalah dalam matematika sehingga merangsang kerja otak untuk menyelesaikan masalah tersebut dengan beragam cara yang mereka pikirkan. Harapannya pada pendekatan ini Siswa tidak semata-mata mendapatkan hasil akhir, akantetapi lebih ditekankan pada proses berpikir bagaimana memperoleh jawaban (Rohaeti, Hendriana dan Sumarmo, 2019)

Kelebihan dari pendekatan open - ended ini siswa dibiasakan menggunakan berbagai metode/ cara bahkan pendekatan yang kreatif dalam menyelesaikan permasalahan matematis yang beragam(Ridwan, 2014) Kemudian situasi yang terbuka dan mendorong timbulnya banyak pertanyaan serta pemberian pandangan dunia lebih bervariasi, lebih fleksibel dan mampu mengeksperikan diri dengan cara berbeda pada umumnya juga merupakan faktor yang mempengaruhi berpikir kreatif yang juga bagian dari proses pendekatan open ended(Asrori, 2015). Hal ini sesuai dengan indikator kemampuan berpikir kreatif sehingga dikatakan bahwa pendekatan pembelajaran Open-eded dapat mempengaruhi kemampuan berpikir kreatif matematis siswa.

Hal ini juga diperkuat dengan penelitian terdahulu oleh Nenden, $\operatorname{dkk(2016)}$ yang menunjukkan bahwa terdapat peningkatan kemampuan berpikir kreatif pada siswa yang 
belajar dengan pendekatan open-ended, yang mana dapat dilihat dari hasil pretest yang diberikan setelah dihitung reratanya adalah 32,3 dan rerata posttest adalah 62,4. Artinya pendekatan open ended bagus dalam peningkatan kemampuan berpikir kreatif matematis dalam pembelajaran matematika.Selanjutnya menurut muhibbin syah (2010) ada faktor internal yang mempengaruhi keberhasilan belajar siswa salah satunya yaitu aspek afektif Salah satu aspek afektif tersebut adalah resiliensi matematis. Dweck (dalam Hendriana dkk., 2017)menyatakan bahwa resiliensi matematis merupakan sikap teguh dan gigih dalam menghadapi kesulitan, bekerja sama dengan teman sebaya untuk penyamaan pendapat dalam menyatukan pemahaman matematika, memeriksa pertanyaan serta berusaha untuk mendapatkan hasil yang tinggi. Adapun indikator resiliensi matematis menurut heris hendriana, Somarmo dan Rohaeti ( 2017) yaitu 1) Menunjukkan sikap tekun, percaya diri, bekerja keras dan tidak mudah menyerah menghadapi masalah, kegagalan, dan ketidakpastian. 2) Menunjukkan keinginan bersosialisasi, mudah memberi bantuan, berdiskusi dengan sebayanya dan beradaptasi dengan lingkungannya. 3) Memunculkan ide/cara baru dan mencari solusi kreatif terhadap tantangan .4) Menggunakan pengalaman kegagalan untuk membangun motivasi diri.5) menciptakan keingintahuan ,merefleksi, meneliti, dan memanfaatkan beragam sumber. 6) Memiliki kemampuan mengontrol diri; sadar akan perasaannya. Berdasarkan latar belakang yang telah diuraikan maka tujuan penelitian ini adalah untuk mengetahui: 1)untuk mengetahui ada tidaknya perbedaan kemampuan berpikir kreatif siswa pada kelas eksperimen (openended) dengan kelas kontrol (konvensional);2) untuk mengetahui ada tidaknya perbedaan kemampuan berpikir kreatif matematis berdasarkan resiliensi; 3) untuk mengetahui ada tidaknya interaksi antara pendekatan openended dengan resiliensi terhadap kemampuan berpikir kreatif Siswa MTs Muhammadiyah 02 Pekanbaru.

\section{Metode Penelitian}

Penelitian ini dilaksanakan di kelas VIII MTs Muhammadiyah 02 Pekanbaru. Jenis penelitian yang digunakan Eksperimen dengan desain penelitian adalah Factorial Eksperimental.Factorial Eksperimental merupakan modifikasi dari design true experimental, yaitu dengan memperhatikan kemungkinan adanya variabel moderator yang mempengaruhi perlakuan terhadap hasil(Hartono, 2019).

Populasi dari penelitian ini adalah seluruh kelas VIII MTs Muhammadiyah 02 Pekanbaru dengan teknik pengambilan sampel cluster random, sehingga diperoleh secara acak yaitu kelas VIII.1 sebagai kelas eksperimen dan VIII.2 sebagai kelas kontrol. Dalam penelitian ini terdapat tiga variabel yaitu variabel bebas adalah pendekatan open ended, variabel terikat adalah kemampuan berpikir kreatif dan variabel moderator adalah resiliensi matematis dengan instrumen penelitian berupa soal tes uraian kemampuan berpikir kreatif, angket, dan lembar observasi, sedangkan analisis data yang digunakan untuk menjawab Hipotesis1) apakah terdapat perbedaan kemampuan berpikir kreatif antar siswa yang belajar dengan pendekatan open ended dengan pembelajaran konvensional. 2)apakah terdapat perbedaan kemampuan berpikir kreatif pada siswa yang 
memiliki resiliensi tinggi, sedang dan rendah. 3) apakah terdapat interaksi antara pendekatan pembelajaran dan resiliensi matematis terhadap kemampuan berpikir kreatif matematis.

Karena dalam penelitian ini menggunakan Desain factorial $2 X_{3}$, maka uji hipotesis menggunakan uji anova dua arah dan untuk melihat tingkat tinggi, sedang dan rendah dalam resiliensi matematis dapat dilihat tabel1 berikut.

Tabel 1.Kriteria Pengelompokan Resiliensi

\begin{tabular}{cc}
\hline Kriteria Resiliensi Matematis & Keterangan \\
\hline$X<\bar{X}-S$ & Kategori Rendah \\
\hline $\bar{X}-S \leq X<\bar{X}+S$ & Kategori Sedang \\
\hline$X \geq X+S$ & Kategori Tinggi \\
\hline
\end{tabular}

(sumber: modifikasi Muhandaz, Trisnawita, \& Risnawati, 2018)

Ket:

$\bar{X}=$ Rerata keseluruhan data kelas eksperimen dan kontrol

$S=S t a n d a r$ Deviasi keseluruhan data kelas eksperimen kontrol

\section{Hasil dan Pembahasan}

\section{Data Hasil Angket Resiliensi Matematis Siswa}

Pengelompokkan resiliensi matematis diperoleh dari hasil angket yang sudah disebarkan ke siswa, kemudian disesuaikan dengan interval resiliensi matematis yang sudah ditentukan hingga terkelompok menjadi resiliensi matematis tingkat tinggi, sedang dan tinggi.
Tabel 2.Pengelompokan Resiliensi Matematis Siswa

\begin{tabular}{ccc}
\hline Kategori & Eksperimen & Kontrol \\
\hline Tinggi & 6 Orang & 4 Orang \\
Sedang & 23 Orang & 28 Orang \\
Rendah & 8 Orang & 4 Orang \\
\hline
\end{tabular}

Berdasarkan perhitungan yang telah dilakukan, maka diperoleh hasil pengelompokkan resiliensi matematis siswa. Pada kelas eksperimen terdapat 6 orang dengan resiliensi matematis tinggi, 23 orang dengan resiliensi matematis sedang dan 8 orang dengan resiliensi matematis rendah. Sedangkan untuk kelas kontrol diperoleh diperoleh 4 orang dengan resiliensi matematis, 28 orang dengan resiliensi matematis sedang dan 4 orang dengan resiliensi matematis rendah.

\section{Data Nilai Pretest Siswa}

Sebelum peneliti menerapkan pendekatan open ended dalam pembelajaran, peneliti memberikan pretest dahulu kepada dua kelas yang dijadikan sebagai objek penelitian dengan analisis secara deskriptif dan infrensial. Hasil pretetst kemampuan berpikir kreatif matematis secara keseluruhan memiliki perbedaan. Pada kelas eksperimen memperoleh skor 6,57 dan kelas kontrol 6,33. Perbandingan rerata hasil pretes disajikan pada gambar 1 berikut: 


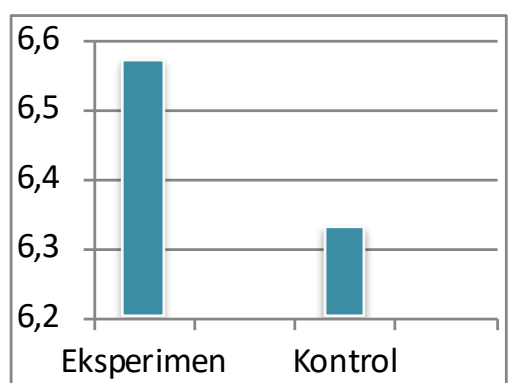

Gambar 1. Rerata Skor Pretest Kelas

Eksperimen dan Kontrol

Agar lebih jelas melihat perbedaan Rerata kemampuan berpikir kreatif matematis antarakelas eksperimen dan kontrol dapat dilihat gambar berikut:

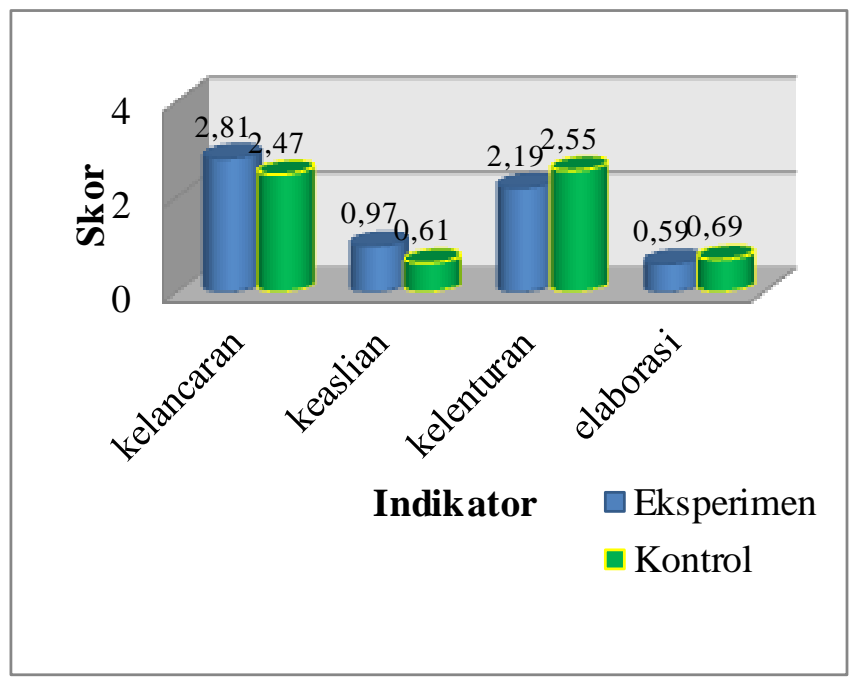

\section{Gambar 2.Rerata Skor Pretest Berdasarkan Indikator Kemampuan Berpikir Kreatif Matematis}

Berdasarkan gambar 2 terlihat kelas yang menggunakan pendekatan open-ended memperoleh rerat skor pretest lebih baik daripada kelas pada pembelajaran konvensional. Untuk soal no. 1-2, terlihat bahwa skor kelas eksperimen lebih tinggi, namun untuk soal no. 3-4 skor kelas kontrol lebih tinggi, hal ini dikarenakan kelas eksperiman lebih bisa menuangkan ide dalam penyelesaian soal, namun untuk soal 3-4 kelas kontrol lebih terperinci dalam indikator elaborasi. Namun secara keseluruhan Reratapretest kelas eksperimen lebih tinggi dari kelas kontrol.

\section{Data Hasil Posttest}

Setelah dilakukannya penelitian pada kelas eksperimen dan kontrol, maka data yang diperoleh di olah secara deskriptif dan inferensial. Untuk hasil skor posttest secara keseluruhan memiliki perbedaan antara kelas eksperimen yaitu 11,5 dan kontrol 9,89. Untuk melihat lebih jelas perbedaan hasil posttest perhatikan gambar 3 berikut:

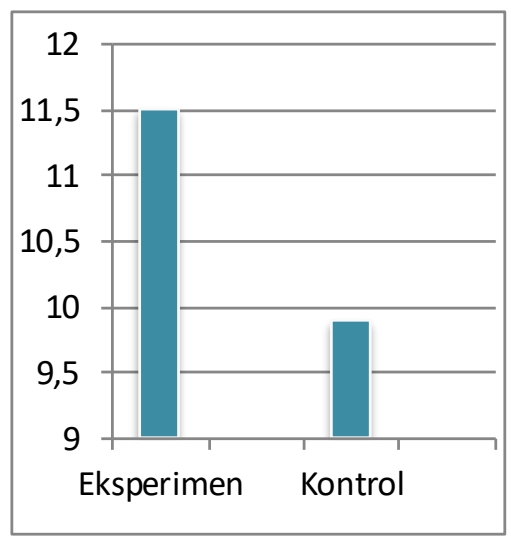

Gambar 3. Rerata Skor Posttest kelas eksperimen dan kontrol

Untuk lebih melihat perbedaan kemampuan berpikir kreatif matematis siswa pada setiap soal secara lebih jelas, maka dapat dilihat diagram berikut. 


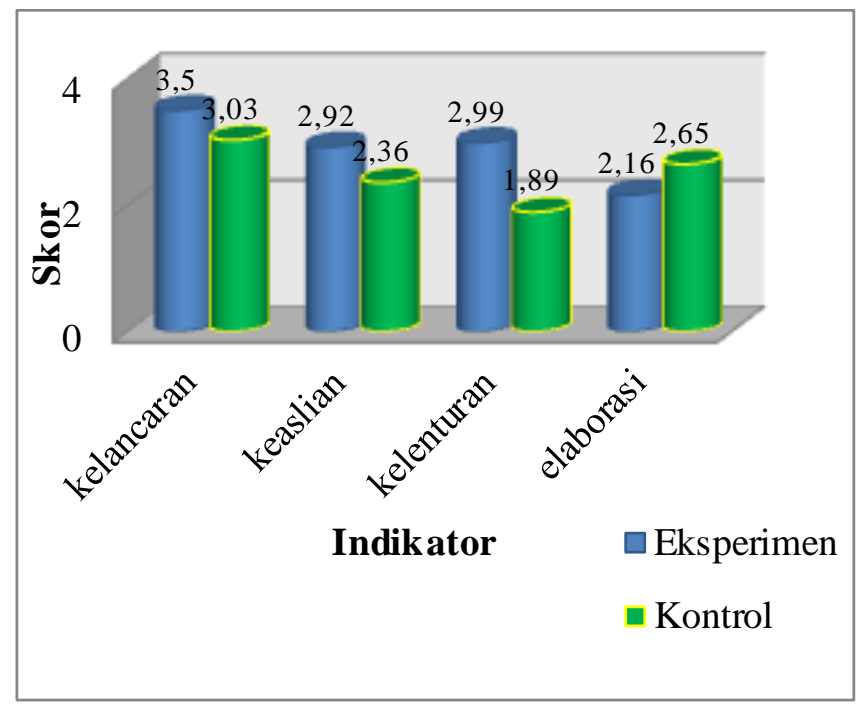

\section{Gambar 4. Rerata Skor Postets Berdasarkan IndikatorKemampuan Berpikir Kreatif Matematis}

Berdasarkan gambar 2 dan 3 terlihat kelas yang menggunakan pendekatan open-ended memperoleh rerata skor lebih baik daripada kelas pada pembelajaran konvensional untuk soal no. 1-3,namun untuk soal no. 4 kelas kontrol memiliki rerata skor lebih tinggi daripada kelas eksperimen, hal ini dikarenakan pada indikator elaborasi, untuk kelas eksperimen banyak jawaban yang tidak terlalu rinci sehingga membuat rerata skor lebih rendah dibanding kelas kontrol. Selain itu rerata postest kemampuan berpikir kreatif matematis juga dapat dilihat perbedaannya pada tingkatan resiliensi, dimana resiliensi mempengaruh kemampuan berpikir kreatif matematis.
Tabel 3. Pengelompokkan Skor Hasil Postest Berdasarkan Tingkat Resiliensi Matematis

\begin{tabular}{lcc}
\hline Kategori & $\begin{array}{c}\text { Jumlah Siswa } \\
\text { ksperimen dan Kontrol) }\end{array}$ & $\begin{array}{c}\text { Rerata } \\
\text { skor }\end{array}$ \\
\hline Tinggi & 10 Siswa & 14 \\
\hline Sedang & 51 Siswa & 10,9 \\
\hline Rendah & 12 Siswa & 5,8 \\
\hline
\end{tabular}

Berdasarkan tabel 3 dapat diketahui bahwa Rerata skor kemampuan berpikir kreatif siswa dalam menjawab soal kemampuan berpikir kreatif berdasarkan tingkat resiliensi tinggi, sedang, rendah memiliki perbedaan. Rerata skor posttest siswa dengan resiliensi matematis tinggi yaitu 14, dan rata - rata siswa dengan resiliensi matematis sedang adalah 10,9, serta rerata skor siswa dengan resiliensi matematis rendah adalah 5,8. Rata - rata hasil posttest berdasarkan tingkat resiliensi matematis dapat dilihat secara rinci pada diagram berikut.

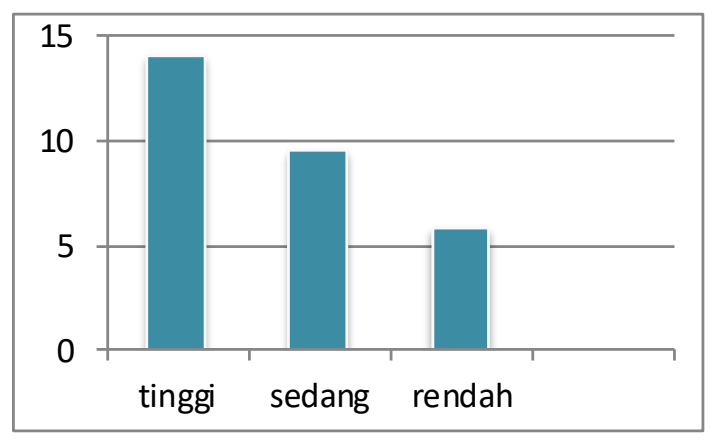

Gambar 5. Perbandingan Skor Hasil Posttest Kelas Eksperimen Dan Kontrol Berdasarkan Resiliensi Matematis

Setelah itu data diolah secara inferensial dengan anova dua arah untuk hipotesis 1,2 dan 
3 namun sebelumnya dilakukan uji prasyarat yaitu normalitas dan homogenitas. Perhatikan tabel berikut:

Tabel 4.Uji Normalitas Postest

\begin{tabular}{|c|c|c|c|c|c|}
\hline $\begin{array}{l}\text { Sumber } \\
\text { Variansi }\end{array}$ & $\begin{array}{l}\mathrm{D} \\
\mathrm{k}\end{array}$ & JK & RK & Fh & $\mathrm{Ft}$ \\
\hline $\begin{array}{c}\text { Antar baris } \\
\text { (Model) } \\
\text { A } \\
\end{array}$ & 1 & 48,35 & $\begin{array}{c}48,3 \\
5\end{array}$ & 8,11 & 3.98 \\
\hline $\begin{array}{c}\text { Antar kolom } \\
\text { (Resiliensi } \\
\text { Matematis) } \\
\text { B }\end{array}$ & 2 & $\begin{array}{c}361,9 \\
4\end{array}$ & $\begin{array}{c}180,9 \\
7\end{array}$ & $\begin{array}{c}30,3 \\
6\end{array}$ & 3,13 \\
\hline $\begin{array}{c}\text { Interaksi } \\
\text { Resiliensi } \\
\text { Matematis*Mo } \\
\text { del } \\
(\mathbf{A} \times \mathbf{B}) \\
\end{array}$ & 2 & 27,72 & 13,86 & 2,32 & 3,13 \\
\hline Dalam & 67 & $\begin{array}{c}399,4 \\
7 \\
\end{array}$ & 5,96 & & \\
\hline Total & 73 & - & - & - & - \\
\hline
\end{tabular}

Dari perhitungan yang telah dilakukan diketahui bahwa $\boldsymbol{L}_{\text {hitung }}$ dari kelas VIII.1 dan kelas VIII.2 lebih kecil dari $\boldsymbol{L}_{\text {tabel }}$ sehingga dapat disimpulkan bahwa data kedua kelas berdistribusi normal. Setelah data berdistribusi normal, maka dilanjutkan dengan uji homogenitas yang disajikan pada tabel berikut:

Tabel 5.Uji Homogenitas Postest

\begin{tabular}{lcc}
\hline \multirow{2}{*}{ Nilai Varians Sampel } & \multicolumn{2}{c}{ Kelas } \\
\cline { 2 - 3 } & VIII.1 & VIII.2 \\
\hline $\mathrm{S}$ & 10,3684 & 11,9025 \\
\hline $\mathrm{N}$ & 37 & 36 \\
\hline
\end{tabular}

$$
F_{\text {hitung }}=\frac{\text { variansterbesar }}{\text { variansterkecil }}=\frac{11,9025}{10,3684}=1,15
$$

Pada taraf signifikan $(\alpha)=0,05$, diperoleh $F_{\text {tabel }}=1,69 \quad$ Karena $\quad F_{\text {hitung }}=1,15$ $\operatorname{dan} F_{\text {tabel }}=1,75$, maka $F_{\text {hitung }}<F_{\text {tabel }}$ atau $1,15<1,75$, sehingga dapat disimpulkan varians-varians adalah HOMOGEN. Setelah dilakukan uji prasyarat normalitas dan homogentis, maka data posttest dilanjutkan dengan uji anova dua arah dengan hasil pada tabel 6 berikut:

Tabel 6.Hasil Uji Anova Dua Arah Postest

\begin{tabular}{cccc}
\hline Kel & $\boldsymbol{x}_{\text {hitung }} \mathbf{L}_{\text {hitung }}$ & $\boldsymbol{x}_{\text {tabel }}^{\mathbf{2}} / L_{\text {tabel }}$ & Kriteria \\
\hline VIII & 9,88 & 12,59 & Normal \\
\hline $\begin{array}{c}1 \\
\text { VIII }\end{array}$ & 2,14 & 12,59 & Normal \\
\hline 2 & & & \\
\hline
\end{tabular}

Dari data pada tabel 6, hasil uji anova dua arah yang disajikan diperoleh hasil sebagai berikut:

1. $F(A)_{\text {hitung }}>F(A)_{\text {tabel }}$ atau $8,11>3,98$ pada signifikansi 5\% yang dapat disimpulkan $H_{a}$ diterima dan $H_{0}$ ditolak. Sehingga Terdapat perbedaan yang signifikan kemampuan berpikir kreatif antara siswa yang belajar dengan menggunakan pendekatan pembelajaran open ended dengan siswa yang belajar menggunakan pembelajaran konvensional.

2. $F(B)_{\text {hitung }}>F(B)_{\text {tabel }}$ atau $30,36>3,13$ pada signifikansi 5\%. Dengan demikian $H_{a}$ diterima dan $H_{0}$ ditolak, sehingga dapat disimpulkan terdapat perbedaan yang signifikan kemampuan berpikir kreatif 
matematis berdasarkan resiliensi matematis tinggi, sedang, dan rendah.

3. $F(A x B)_{\text {hitung }}<F(A x B)_{\text {tabel }}$ atau $2,32<$ 3,14. Dengan demikian $H_{0}$ diterima dan $H_{a}$ ditolak,sehingga dapat disimpulkan tidak terdapat interaksi penerapan pendekatan pembelajaran dan resiliensi matematis siswa terhadap kemampuan berpikir kreatif matematis.

Dari hasil pengujian hipotesis $1 \mathrm{~F}_{\text {hitung }}=$ 8,11 sedangkan $\mathrm{F}_{\text {tabel }}$ dengan derajat kebebasan $(\mathrm{dk})=1$, pada taraf signifikan $5 \%$ adalah 3,98. Berdasarkan hasil analisis menunjukkan bahwa $\mathrm{F}_{\text {hitung }}>\mathrm{F}_{\text {tabel }}$ atau 8,11> 3,98, maka disimpulkan terdapat perbedaan kemampuan berpikir kreatif matematis antara siswa yang belajar menggunakan pendekatan pembelajaran open ended dengan siswa yang menggunakan pembelajaran konvensional. Hal ini juga ditunjukkan dari hasil Rerata skor kelas eksperimen yang lebih tinggi dari pada Rerata skor kelas kontrol yaitu 11,5 dan 9,89. Itu artinya hipotesis pertama membuktikan teori yang dikemukakan oleh Aris Shoimin(2017) yang menyatakan bahwa dengan diterapkannya pendekatan open- ended artinya guru memberikan peluang untuk siswa dalam menemukan pengetahuan/pengalaman untuk menemukan, mengenali, dan menyelesaikan masalah dengan beberapa teknik/ cara. Hal tersebut sependapat dengan hasil penelitian yang dilakukan oleh Suriyani, dkk (2015)yang menyimpulkan bahwa meningkatnya kemampuan berpikir kreatif siswa dengan penerapan pendekatan open-ended. Kemudian oleh Nenden dan Nur Aeni(Faridah et al., 2016) Yang menunjukkan bahwa terdapat peningkatan kemampuan berpikir kreatif pada siswa yang belajar dengan pendekatan openended, yang mana dapat dilihat dari hasil pretest yang diberikan setelah dihitung reratanya adalah 32,3 dan rerata posttest adalah 62,4. Berikut salah satu lembar jawaban siswa kelas eksperimen dan kelas kontrol untuk melihat perbedaan kemampuan berpikir kreatif matematis.

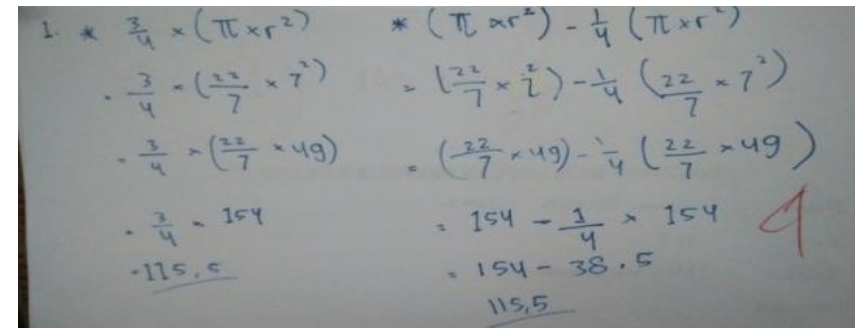

\section{Gambar 6. Lembar Jawaban Siswa Kelas Eksperimen}

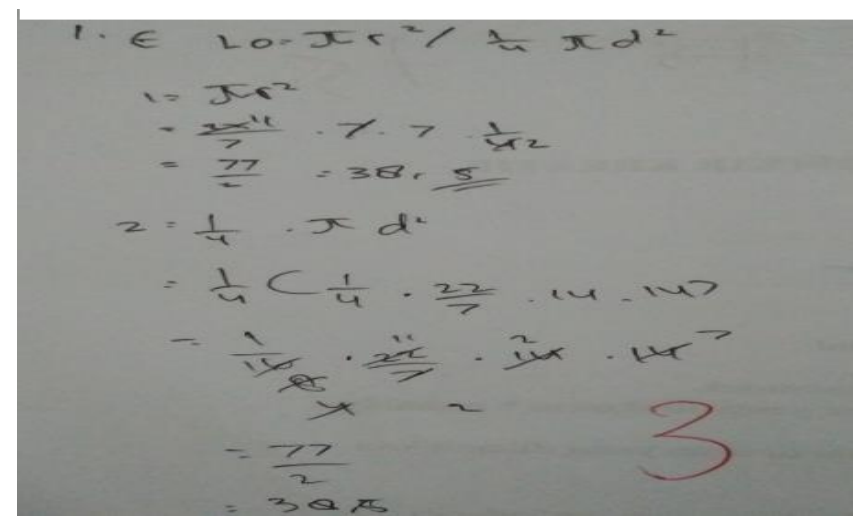

Gambar 7. Lembar Jawaban Siswa Kelas Kontrol 
Dari gambar 6 dan gambar 7 dapat dijelaskan bahwa siswa kelas eksperimen mampu menyelesaikan soal dengan baik dengan 2 cara berbeda dan hasil akhir juga benar, namun untuk kelas kontrol walaupun mempunyai jawaban dengan cara berbeda namun hasil akhir masih salah

Kemudian untuk melihat ada tidaknya perbedaan kemampuan berpikir kreatif antara siswa dengan resiliensi matematis tinggi, sedang dan rendah dianalisis dengan anova dua arah memproleh $F(B)_{\text {hitung }}>F(B)_{\text {tabel }}$ atau 30,36>3,13, artinya terdapat perbedaan kemampuan berpikir kreatif matematis berdasarkan resiliensi matematistinggi, sedang, dan rendah siswa. Hal ini ditunjukkan pada skor siswa dengan resiliensi matematis tinggi yang diajarkan dengan pendekatan pembelajaran open-ended memperoleh rerata skor kemampuan berpikir kreatif 14,5 sedangkan pada pembelajaran tanpa pendekatan pembelajaran open-ended memperoleh rerata skor kemampuan berpikir kreatif 13,75. Kemudian pada ketagori resiliensi sedang siswa yang diajarkan dengan pendekatan pembelajaran open-ended memperoleh rerata skor kemampuan berpikir kreatif 12 sedangkan pada pembelajaran tanpa pendekatan pembelajaran open-ended memperoleh rerata skor kemampuan berpikir kreatif 9,93. untuk ketagori resiliensi rendah siswa yang diajarkan dengan pendekatan pembelajaran open-ended memperoleh rerata skor kemampuan berpikir kreatif 7 sedangkan pada pembelajaran tanpa pendekatan pembelajaran open-ended memperoleh rerata skor kemampuan berpikir kreatif 4,75. hal inipun sejalan dengan penelitian yang dilakukan oleh Indiraningrum, dkk( 2018) dalam jurnalnya dengan judul Kemampuan Berpikir Kreatif Matematik Siswa MTs Ditinjau Dari Resiliensi Matematik menunjukkan hasil bahwa siswa yang memiliki resiliensi matematis tinggi memperoleh skor $>79$,untuk siswa dengan resiliensi matematis sedang memperoleh skor $69<$ skor < 79 sedangkan siswa dengan resiliensi rendah memperoleh skor <69.hal ini membuktikan bahwa dengan resiliensi matematis tinggi maka kemampuan berpikir kreatif juga lebih bagus di bandingkan dengan resiliensi matematis sedang dan rendah. Selanjutnya penelitian oleh Siska Chindy Dilla, $\operatorname{dkk}(2018)$ meneliti faktor gender dan resiliensi yang menyimpulkan bahwa siswa dengan resiliensi matematis tinggi akan lebih tangguh dalam menyelesaikan masalah dan siswa dengan resiliensi matematis kurang akan lebih takut salah dan tidak mau berusaha dalam menyeleaikan masalah matematis baik pada siswa laki-laki maupun perempuan, artinya tingkat resiliensi matematis siswa mempunyai pengaruh terhadap kemampuan berpikir kreatif matematis siswa. Berikut bukti salah satu lembar jawaban siswa yang mempunyai resiliensi matematis ringgi, sedangdan rendah. 


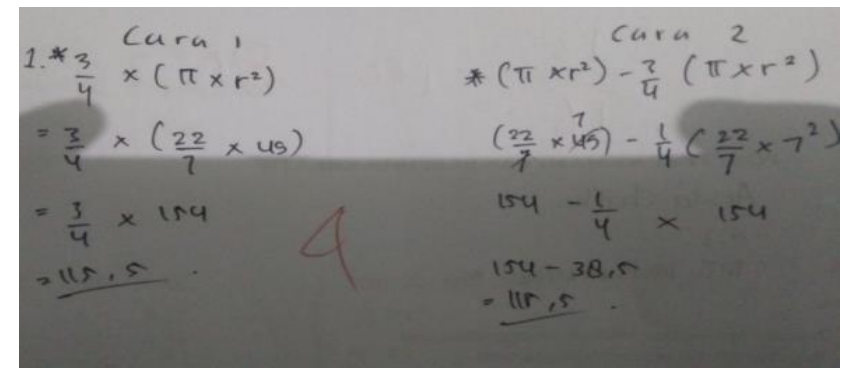

Gambar 8. Lembar jawaban siswa dengan resiliensi matematis tinggi

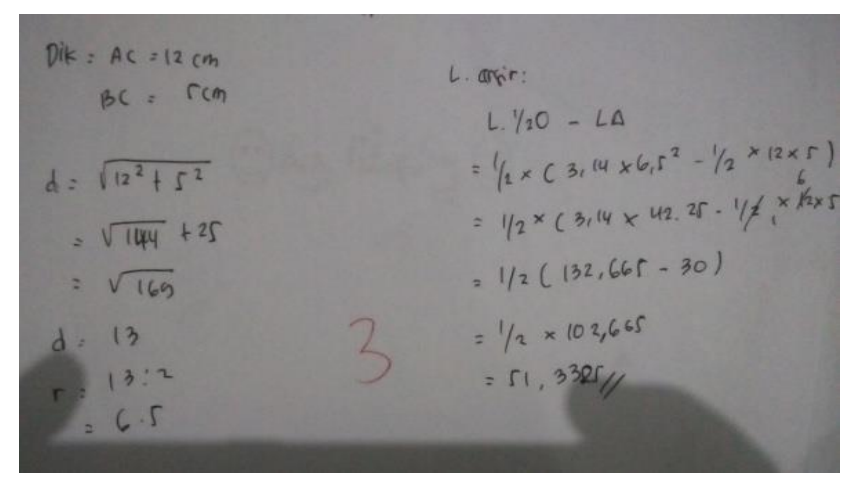

Gambar 9. Lembar jawaban siswa dengan resiliensi matematis sedang

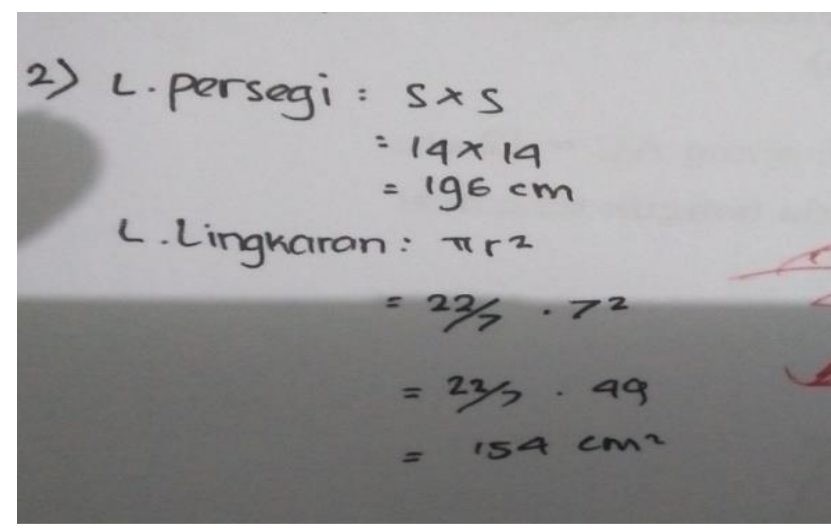

Gambar 10. Lembar jawaban siswa dengan resiliensi matematis rendah

Selanjutnya untuk melihat terdapat atau tidak interaksi antara pendekatan dengan resiliensi matematika terhadap kemampuan berpikir kreatif maka dari hasil uji anova dua arah juga diperoleh hasil $F(A x B)_{\text {hitung }}<$ $F(A \times B)_{\text {tabel }}$ atau $2,32<3,14$, artinya tidak ada interaksi pendekatan pembelajaran dengan resiliensi matematis siswa terhadap kemampuan berpikir kreatif matematis. Hasil tersebut sesuai dengan yang diutarakan oleh panitz (dalam Suprapto, 2015) yaitu tidak adanya interaksi antara pendekatan/model/strategi yang diterapkan pada pembelajaran dengan variabel moderatornya seperti resiliensi terhadap variabel terikat yaitu kemampuan matematis siswa karena adanya pengaruh utama yang dominan/kuat dari variabel bebas dan variabel moderat terhadap variabel terikat, sehingga memperkecil atau memperlemah interaksi yang ada. Berikut bukti lembar jawaban siswa kelas eksperimen dan kontrol.

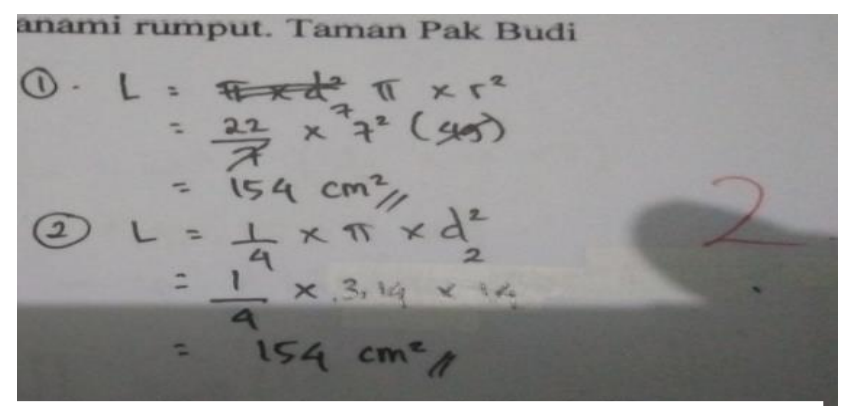

Gambar 11. Lembar jawaban siswa dengan resiliensi matematis tinggi

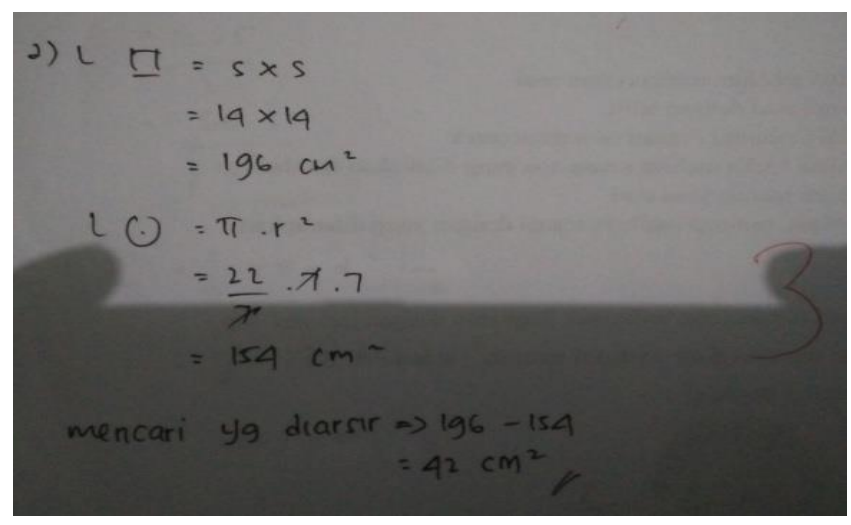

Gambar 12. Lembar jawaban siswa dengan resiliensi matematis rendah 


\section{Simpulan dan Saran}

Berdasarkan hasil penelitian yang telah dilakukan, maka peneliti menyimpulkan: 1) Terdapat perbedaan yang signifikan kemampuan berpikir kreatif antara siswa yang belajar dengan menggunakan pendekatan pembelajaran open ended dengan siswa yang belajar menggunakan pembelajaran konvensional, dimana siswa yang menggunakan pendekatan open-ended lebih baik dari segi rerata hasil tes kemampuan berpikir kreatif; 2)Terdapat perbedaan kemampuan berpikir kreatif berdasarkan resiliensi matematis, dimana rerata tes kemampuan berpikir kreatif pada resiliensi tinggi lebih baik dari resiliensi sedang maupun resiliensi rendah;3) Serta Tidak terdapat interaksi antara pendekatan pembelajaran dengan resiliensi matematis siswa terhadap kemampuan berpikir kreatif matematis. Saran yang diberikan peneliti agar penelitian berjalan dengan baik adalah pemanfaatan waktu sebaik mungkin dalam proses siswa mencari berbagai jawaban harus dikontrol agar terarah.

\section{Referensi}

Asrori, M. (2015). Perkembangan Peserta Didik. Yogyakarta: Medika Akademi.

Dilla, S. C., Hidayat, W., \& Rohaeti, E. E. (2018). Faktor gender dan resiliensi dalam pencapaian kemampuan berpikir kreatif matematis siswa SMA. Journal of Medives: Journal of Mathematics Education IKIP Veteran Semarang, 2(1), 129-136.
Faridah, N., Aeni, A. N., \& others. (2016). Pendekatan Open-Ended Untuk Meningkatkan Kemampuan Berpikir Kreatif Matematis Dan Kepercayaan Diri Siswa. Jurnal pena ilmiah, 1(1), 10611070.

Hartono. (2019). Metodologi Penelitian. Pekanbaru: Zanafa Publishing.

Hendriana, H., Rohaeti, E. E., \& Sumarmo, U. (2017). HardSkill dan Soft Skill. Bandung: Refika Aditama.

Istarani, \& Ridwan, M. (2014). 50 Tipe Pembelajaran Kooperatif. Medan: CV. Media Persada.

Lestari, K. E., \& Yudhanegara, M. R. (2017). Penelitian Pendidikan Matematika. Bandung: PT Refika Aditama.

Muhandaz, R., Trisnawita, O., \& Risnawati, R. (2018). Pengaruh Model Pembelajaran Course Review Horay terhadap Kemampuan Pemahaman Konsep Matematis Berdasarkan Kemandirian Belajar Siswa SMK Pekanbaru. JURING (Journal for Research in Mathematics Learning), 1(2), 137. https://doi.org/10.24014/juring.v1i2.6552

Pratiwi, I., Yulianti, D., \& Fitrianna, A. Y. (2018). Kemampuan Berpikir Kreatif Matematik Siswa MTs Ditinjau Dari Kemampuan Resiliensi Matematik Siswa. JPMI (Jurnal Pembelajaran Matematika Inovatif), 1(2), 171-184.

Putra, H. D., Akhdiyat, A. M., Setiany, E. P., \& Andiarani, M. (2018). Kemampuan Berpikir Kreatif Matematik Siswa SMP di Cimahi. Kreano, Jurnal Matematika Kreatif-Inovatif, 9(1), 47-53. 
Safari, Sri Anandari dan M. Syarwa Sangila(2019). Kemampuan Berpikir Kreatif Matematis Siswa SMP Pada Materi Bangun Datar, 73-90.

Shoimin, A. (2017). 68 Model Pembelajaran Inovatif Dalam Kurikulum 2013. Yogyakarta: Ar-Ruzz Media.

Suprapto, E. (2015). Pengaruh model pembelajaran kontekstual, pembelajaran langsung dan motivasi berprestasi terhadap hasil belajar kognitif. Innovation of Vocational Technology Education, 11(1).

Suriyani, S., Hasratuddin, H., \& Asmin, A. (2015). Peningkatan kemampuan berpikir kreatif dan kemandirian belajar siswa mts negeri 2 medan melalui pembelajaran matematika dengan pendekatan open-ended. TABULARASA, 12(3).

Syah, M. (2010). Psikologi Pendidikan Dengan Pendekatan Baru. Bandung: PT. Remaja Rosdakarya. 